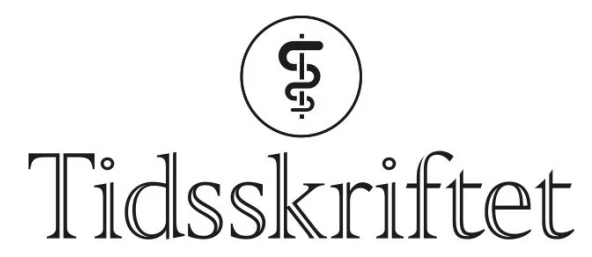

DEN NORSKE LEGEFORENING

\title{
Metaanalyse: fast eller tilfeldig
}

\author{
MEDISIN OG TALL \\ ARE HUGO PRIPP \\ apripp@ous-hf.no \\ Are Hugo Pripp er forsker og biostatistiker ved Oslo senter for biostatistikk og epidemiologi, \\ Forskningsstøtteavdelingen, Oslo universitetssykehus. Han er professor II ved Fakultet for \\ helsevitenskap, OsloMet - Storbyuniversitetet. \\ Forfatteren har fylt ut ICMJE-skjemaet og oppgir ingen interessekonflikter.
}

\section{Det er to hovedmetoder for metaanalyse - faste eller tilfeldige effekter. Disse bygger på forskjellige antagelser om studiene som inngår i metaanalysen.}

Forskjellige studier kan gi forskjellige resultater selv når de undersøker det samme. Noen finner at aktiv behandling er bedre enn kontrollbehandling, andre at de er like gode, og enkelte hevder at kontrollbehandlingen var best hele tiden. Resultater blir analysert og presentert med et stort mangfold fra studie til studie. Fra bunken med forskningsartikler som skulle oppklare det hele, blir det en rikholdig blanding av gjennomsnitt, p-verdier, medianer og krysstabeller, samt flere ekspertuttalelser enn det er eksperter. Da er metaanalyse en statistisk metode som kan rydde opp i virvaret og gi et mer entydig resultat. Kvaliteten på en metaanalyse avhenger av en rekke faktorer. Er de utvalgte studiene egentlig den samme studien gjentatt flere ganger eller er hver studie en unik, men tilstrekkelig sammenlignbar, undersøkelse av det samme fenomenet?

\section{To forskjellige antagelser}

La oss for eksempel tenke oss at flere forskningsgrupper undersøker det samme medikamentet mot kolesterol på et meget likt utvalg av pasienter. Målemetodene og analysene av resultatene er tilsvarende i alle artiklene. Da er det rimelig å anta at de på sett og vis gjentar den samme studien hver for seg, og den «sanne» effekten - statistisk kaller vi ofte dette for populasjonseffekten - av medikamentet antas å være den samme - «fast» - i alle studiene. De observerte forskjellene skyldes dermed bare naturlig statistisk variasjon. En metaanalyse med fast effekt er da et fornuftig valg. Vi oppnår et samlet estimat av de identiske «sanne» effektene i alle studiene, men med en høyere presisjon enn i hver og en av $\operatorname{dem}(\underline{1})$.

La oss ta et annet eksempel: Forskningsgruppene undersøker effekten av trening etter hoftebruddsoperasjon sammenliknet med vanlig oppfølging. Inklusjon av pasienter og intensitet og varighet av treningsøvelsene er vidt forskjellig mellom studiene. Noen måler 
balanse, mens andre måler ganghastighet eller utholdenhet. Studiene undersøker det samme fenomenet og er for så vidt sammenlignbare, men den «sanne» effekten av trening er høyst sannsynlig forskjellig fra studie til studie. Da er det riktig å bruke tilfeldige effekter som modell for metaanalysen. Det samlete resultatet av metaanalysen blir et gjennomsnitt av de ulike "sanne» effektene som varierer "tilfeldig» mellom studiene. Den observerte forskjellen mellom studiene skyldes både naturlig statistisk variasjon og varierende sanne effekter fra studie til studie. Valg av metode påvirker både tolkningen av resultatene og vektleggingen av studiene mot hverandre (2) $)$. Figur 1 illustrerer den prinsipielle forskjellen mellom faste og tilfeldige effekter som modell for metaanalyse.
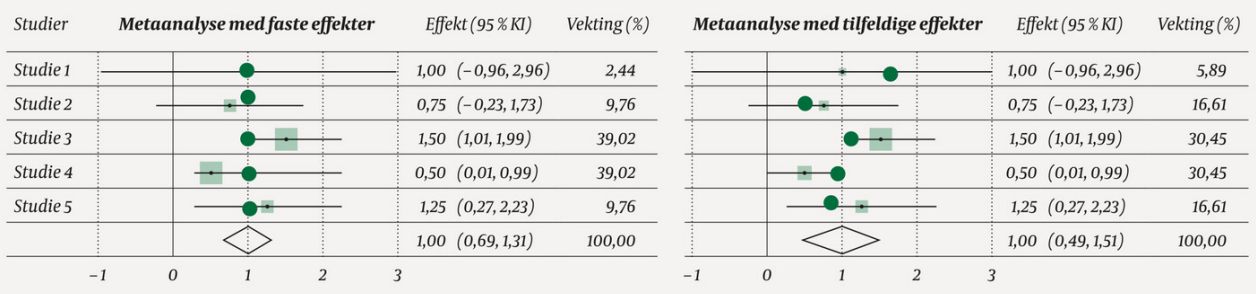

Figur 1 En illustrasjon av den prinsipielle forskjellen mellom metaanalyser med ulike antagelser. I en fast effekt-metaanalyse antar vi at den sanne effekten er lik i hver studie, mens vi antar den varierer, men er tilstrekkelig sammenlignbar i en tilfeldige effektermetaanalyse. De sanne (ukjente) effektene er illustrert med grønne sirkler, de observerte effektene med tilhørende konfidensintervaller er vist med firkanter og linjer, og det overordnete resultatet fra de to metodene er vist nederst i de to balansediagrammene.

\section{Fast, tilfeldig eller begge deler}

Kjennskapen om de inkluderte studiene bør i stor grad avgjøre om vi bruker en metaanalyse med faste eller tilfeldige effekter. Ved hjelp av en test for heterogenitet kan man vurdere hvor mye av den samlete variasjonen mellom studiene som skyldes forskjellene til de sanne effektene i forhold til den naturlige statistiske variasjonen. Omfanget av heterogenitet kan estimeres ved $\mathrm{I}^{2}$ og testes for eksempel med Cochrans Q-test (3). Resultatene fra slike analyser bør oppgis som del av metaanalysen uansett valg av metode. F.eks. hadde metaanalysen i figur 1 en I² på 52,9\% og p-verdien til Cochrans Qtesten var 0,075. En høy grad av heterogenitet og en signifikant Cochrans Q-test taler for å velge en tilfeldige effekter-metaanalyse. Studiene kan også være så forskjellige at de i liten grad er sammenlignbare og dermed ikke egnet for en metaanalyse. Da løser ikke tilfeldige effekter problemet.

Enkelte statistikere argumenter for alltid å utføre en analyse med tilfeldige effekter, fordi fast effekt-metoden kan overestimere presisjonen (4). Etter å ha valgt og presentert resultatene med den ene metoden, kan man oppgi resultatet fra den andre metoden som en sensitivitets- og robusthetsanalyse.

\section{LITTERATUR}

1. Borenstein M, Hedges LV, Higgens JPT et al. Fixed-effect model. I: Introduction to meta-analysis. Chichester: John Wiley \& Sons, Ltd, 2009: 63-7.

2. Borenstein M, Hedges LV, Higgens JPT et al. Random-effects model. I: Introduction to metaanalysis. Chichester: John Wiley \& Sons, Ltd, 2009: 69-75.

3. Cheung MWL, Ho RCM, Lim Y et al. Conducting a meta-analysis: basics and good practices. Int J Rheum Dis 2012; 15: 129-35. [PubMed][CrossRef]

4. Schmidt FL, Oh IS, Hayes TL. Fixed- versus random-effects models in meta-analysis: model properties and an empirical comparison of differences in results. Br J Math Stat Psychol 2009; 62: 97128. [PubMed][CrossRef] 
Publisert: 20. juli 2021. Tidsskr Nor Legeforen. DOI: 10.4045/tidsskr.21.0387

(C) Tidsskrift for Den norske legeforening 2023. Lastet ned fra tidsskriftet.no 26. april 2023. 